\title{
ESTIMATED SUPPLY OF GREEN OPEN SPACE IS BASED ON OXYGEN CONSUMPTION AND MICRO TEMPERATURES IN CARUBAN CITY
}

\author{
Ronnawan Juniatmoko ${ }^{1}$ \\ ${ }^{1}$ Centre of Science and Technology, IAIN Surakarta \\ Email: ronnawan.juniatmoko@iain-surakarta.ac.id
}

\begin{abstract}
Local governments must provide a public green space for $20 \%$ of the total city area. In addition for aesthetic value and beauty that is used as source of public recreation and green space that used to create cooler microclimate temperatures, maintain the balance of oxygen $\left(\mathrm{O}_{2}\right)$ and carbondioxide $\left(\mathrm{CO}_{2}\right)$, reduce pollutants, and help maintain water availability soil. Research aims to analyze and calculate the needs of Caruban City Green Space. Research used survey method with purposive sampling technique and secondary data analysis. Temperature analysis used the thom formula, while the analysis the needs of green space with the Geravkis method. Results of study showed that in six places had relatively cooler temperatures ranging from $26-31^{\circ} \mathrm{C}$ in the afternoon, $26-33^{\circ} \mathrm{C}$ in the morning, and in the middle of afternoon about 29 to $33^{\circ} \mathrm{C}$. Data showed that in one place, namely, Ahmad Yani road showed the temperature about $31-36.5^{\circ} \mathrm{C}$ was relatively hot. Oxygen demand in 2020 requires a full green space of $133.92 \mathrm{ha}$. The results of this study are expected to provide recommendations in the application of Spatial Planning Law Number 26 of 2007 concerning spatial planning to improve the comfort of Caruban City dwellings in terms of the air environment.
\end{abstract}

Keywords: $\mathrm{O}_{2}$, Green Open Space, Temperature

\section{A. INTRODUCTION}

Madiun Regency, with its capital Caruban City, is one of the regencies in East Java Province. The city has a strategic location which is located on the primary arterial road leading to the provincial capital of Surabaya and connects the city of Solo, as well as a border city between East Java Province and Central Java Province. Madiun Regency and its capital Caruban City is one of the districts in East Java Province. The city has a strategic location which is located on the primary arterial road leading to the provincial capital of Surabaya and connects the city of Solo, as well as a border city between East Java and Central Java Province.

Based on (Peraturan Pemerintah Republik Indonesia Nomor 3 Tahun 2019 Tentang Perubahan Atas Peraturan Pemerintah Nomor 52 Tahun 2010 Tentang Pemindahan Ibu Kota Kabupaten Madiun Dari Wilayah Kota Madiun Ke Wilayah Kecamatan Mejayan Kabupaten Madiun Provinsi Jawa $\mathrm{Ti}, 2019$ ), the consequences of establishing the Caruban city Area to be 
the Capital City of Madiun Regency require the availability of land to support its function as the capital of the regency. This includes the obligation to provide green space. Local governments must provide a public green space of $20 \%$ of the total area of the city. The availability of green space is essential for urban areas such as the Caruban city.

Urban vegetation can also improve the quality of life and enable people to come into contact with nature, improving their comfort levels. The integration of green spaces in urban planning and architectural design is therefore essential for adapting to and mitigating the thermal shocks of local and urban heat island processes (Xiao et al., 2018). Besides adding aesthetic value and usefulness of the city that is useful as a source of public recreation, actively or passively, green space also functions to create a cooler

\section{B. MATERIALS AND METHODS}

This study uses a combination of survey method with purposive sampling technique, in which sampling is based on certain characteristics that are considered to have a relationship with population characteristics that have been known previously. In other words, sampling is based on characteristics that microclimate, maintain a balance of oxygen $(\mathrm{O} 2)$ and carbon dioxide (CO2), reduce pollutants, and help maintain groundwater availability.

The provision of urban green open space in Indonesia is mostly based on total area (30\% of green open space) population, oxygen demand, $\mathrm{CO} 2$ emissions, the needs for certain functions, and public perception. However, these methods deliver different outputs about how much area is needed for green open space. These methods also could not determine the priority locations as the new additional green open space to reduce urban temperatures (Humaida et al., 2016).

The data above is secondary data used in the calculation of the estimated green space in Caruban City. This study aims to analyze and evaluate the need for green open space to micro air temperatures in Caruban City.

fit the purpose of the study and secondary data analysis. The technique in this study uses purposive sampling technique. The subject in this study is the Caruban city. According to (BPS, 2019a, 2019b), the total population at the end of 2019 in urban areas and their area is shown in table 1 below: 
Table 1. The total population at the end of 2019 in urban areas along with the area.

\begin{tabular}{cccc}
\hline No & Village & $\begin{array}{c}\text { Total Population End of 2019 } \\
(\text { people) }\end{array}$ & $\begin{array}{c}\text { An area } \\
(\mathbf{H a})\end{array}$ \\
\hline 1 & Krajan & 4.308 & 71,89 \\
\hline 2 & Mejayan & 4.960 & 274,66 \\
\hline 3 & Bangunsari & 4.222 & 132,46 \\
\hline 4 & Pandean & 2.079 & 47,08 \\
\hline & Jumlah Total & $\mathbf{1 5 . 5 6 9}$ & $\mathbf{5 2 6 , 2 3}$ \\
\hline
\end{tabular}

Source: (BPS, 2019b)

The data above is secondary data used in the calculation of the estimated green space in Caruban City. This study aims to analyze and evaluate the need for green open space to micro air temperatures in Caruban City.

Temperature analysis using ideal temperature analysis using the thom formula, while the analysis of the needs of green space by the Gerakis method. Temperature analysis using ideal
Temperature Analysis. Ideal temperature, determined from the results of morning temperature measurements, afternoon and evening using the Thom formula (Wati \& Fatkhuroyan, 2017).

$$
\begin{aligned}
& \text { TI : } 0.2(\mathrm{Ts}+\mathrm{Tp})+15, \text { or } \\
& \text { TI : } 0.2(\text { Tmax }+ \text { Tmin })+15 \\
& \text { meaning : } \\
& \text { Ts : Temperatur daytime } \\
& \text { Tp : Temperatur morning } \\
& \text { Tmax : Temperatur maksimum } \\
& \text { Tmin : Temperatur minimum }
\end{aligned}
$$

Table 2. Temperature Indices on Climate Conditions

\begin{tabular}{cccc}
\hline No. & Symbol & Index Temperatur $\left({ }^{\circ} \mathbf{C}\right)$ & Climate conditions \\
\hline 1 & $\mathrm{~T}_{1}$ & $<21.1$ & very cold \\
\hline 2 & $\mathrm{~T}_{2}$ & $21.1-23.1$ & cold \\
\hline 3 & $\mathrm{~T}_{3}$ & $23.2-25.1$ & rather cold \\
\hline 4 & $\mathrm{~T}_{4}$ & $25,2-27.1$ & cool \\
\hline 5 & $\mathrm{~T}_{5}$ & $27.2-29.1$ & rather hot \\
\hline 6 & $\mathrm{~T}_{6}$ & $29.2-31.1$ & hot \\
\hline 7 & $\mathrm{~T}_{7}$ & $>31.1$ & very hot \\
\hline
\end{tabular}


While the analysis of the needs of green space is determined from secondary data calculated using the Gerakis method : (Dasuka et al., 2016). $L t=\frac{P t+K t+T t}{(54)(0,9375)(2)} m^{2}$

$\mathbf{L t}$ : the area of Green City int $\left(\mathrm{m}^{2}\right)$ $\mathbf{P t}$ : the amount of oxygen needed for the population in the year $t$

$\mathbf{K t}$ : the amount of oxygen needed for motor vehicles in the $t$ year

$\mathbf{T t}$ : the amount of oxygen needed for livestock in the year $\mathrm{t}$

54 : a constant indicating that $1 \mathrm{~m} 2$ of the land area produces 54 grams of plant dry weight per day

0.9375 : a constant indicating that 1 gram of plant dry weight is equivalent to 0.9375 gram oxygen production

2 : the number of seasons in Indonesia
Some assumptions that will be used in this calculation are as follows:

- Oxygen users are humans and motorized vehicles. Livestock are ignored because they are less relevant for use in the context of urban areas.

- The oxygen demand of the population is the same, which is equal to 600 litres/day or 864 gr/day

- Oxygen demand standards for each type of motor vehicle are obtained from the results of previous.

The following is oxygen consumption (Santi et al., 2019):

Table 3. Oxygen consumption

\begin{tabular}{|c|c|c|c|c|}
\hline No & Consumer & Category & $\begin{array}{c}\text { Oxygen Needs } \\
\text { (gr/day) }\end{array}$ & Information \\
\hline 1 & Human & & 864 & \\
\hline 2 & \multirow{4}{*}{ Vehicle } & Passenger car & 11.630 & 3 hour/day \\
\hline 3 & & Bus & 45.760 & 3 hour/day \\
\hline 4 & & Truck & 22.880 & 2 hour/day \\
\hline 5 & & Motor cycle & 580 & 1 hour/day \\
\hline
\end{tabular}


Oxygen demand per consumer

Oxygen demand per oxygen consumer

Source: (Setyani et al., 2017)

- The number of vehicles operating within the city is obtained from the average daily traffic data of the vehicle.

- Oxygen is only produced by plants and oxygen supply from outside the city area is ignored in the calculation.

\section{Place and time of research}

The study was conducted in urban Mejayan there are four villages and Sub-district in the region. Mejayan Village, Krajan Village, Bangunsari Village, Pandean Village. The research sites were conducted in 7 places with details 1 in the form of Field, 1 Green Line, 1 River Basin and 4 Parks determined according to characteristics and air temperature data collection carried out for three days.

\section{Research Tools and Materials}

Tools and materials used:

1. A set of PC

2. A printer

\section{RESULTS AND DISCUSSION} Analysis of Ideal Temperature

It is obtained from the results of measurements in the field using a temperature thermohygrometer at seven observation locations in 4 urban villages, namely Krajan, Bangunsari, Pandean, and Mejayan. Held Sunday (December
3. Meter and Handheld GPS

4. A set of stationery

5. Microsoft Office (Mc. Word, Mc. Excel 2016)

6. Thermohygrometer temperature measuring devices

The data used in this study are secondary data and primary data in the form of:

1. Population data,

2. Data on the number of motorized vehicles,

3. Morning, afternoon and evening air temperature data, and

4. Area data

\section{Sampling measurement)}

(temperature

In a day measurements are taken from 06:00 to 18:00. with the division of morning (6am - 10am), afternoon (10am - 2pm), afternoon (2am - 6pm).

This calculation tries to convert oxygen demand into the area of green space that must provide to meet those needs. The base is the population of a city, and the administrative boundaries of each city limit this study.

$15,2019)$ as a non-busy day and Tuesday and Thursday (January 7, 2020, and March 12, 2020) as a day of heavy traffic. The following table provides the results of measurement measurements with ideal temperature analysis: 
Table 4. Temperature measurement table and Ideal Temperature analysis results

\begin{tabular}{|c|c|c|c|c|c|c|c|}
\hline \multirow{3}{*}{ No. } & \multirow{3}{*}{ LOCATION } & \multicolumn{4}{|c|}{ OBSERVATION OF TEMPERATURE ${ }^{0} \mathrm{C}$} & \multirow{3}{*}{$\begin{array}{c}\text { IDEAL } \\
\text { TEMPERATURE }\end{array}$} & \multirow{3}{*}{ CATEGORY } \\
\hline & & \multirow{2}{*}{ DATE } & MOR & \multirow{2}{*}{$\begin{array}{l}\text { AFTER } \\
\text { NOON }\end{array}$} & \multirow{2}{*}{$\begin{array}{c}\text { EVENI } \\
\text { NG }\end{array}$} & & \\
\hline & & & NING & & & & \\
\hline \multirow{3}{*}{1} & \multirow{3}{*}{$\begin{array}{l}\text { J1. Panglima } \\
\text { Sudirman } \\
\text { (Taman Lalu } \\
\text { Lintas) }\end{array}$} & 15 Des 2019 & 23,8 & 29,6 & 25,8 & 25,68 & cool \\
\hline & & 7 Jan 2020 & 24,0 & 31,8 & 29,8 & 26,16 & cool \\
\hline & & 12 Maret 2020 & 25,0 & 31,4 & 27,6 & 26,28 & cool \\
\hline \multirow{3}{*}{2} & \multirow{3}{*}{$\begin{array}{l}\text { J1. Panglima } \\
\text { Sudirman } \\
\text { (Rest Area } \\
\text { Pasar } \\
\text { Burung) }\end{array}$} & 15 Des 2019 & 23,8 & 31,0 & 27,8 & 25,96 & cool \\
\hline & & 7 Jan 2020 & 23,8 & 31,2 & 28,0 & 26 & cool \\
\hline & & 12 Maret 2020 & 25,6 & 28,2 & 27,0 & 25,76 & cool \\
\hline \multirow{3}{*}{3} & \multirow{3}{*}{$\begin{array}{l}\text { J1. Panglima } \\
\text { Sudirman } \\
\text { (Taman } \\
\text { Mejayan } \\
\text { Asti) }\end{array}$} & 15 Des 2019 & 26,6 & 31,2 & 25,0 & 26,56 & cool \\
\hline & & 7 Jan 2020 & 23,6 & 32,8 & 30,2 & 26,28 & cool \\
\hline & & 12 Maret 2020 & 24,6 & 31,6 & 28,2 & 26,24 & cool \\
\hline \multirow{3}{*}{4} & \multirow{3}{*}{$\begin{array}{l}\text { Jl. Ahmad } \\
\text { Yani } \\
\text { (Pertigaan } \\
\text { Jalan Besar) }\end{array}$} & 15 Des 2019 & 26,2 & 36,5 & 25,8 & 27,54 & Rather hot \\
\hline & & 7 Jan 2020 & 26,4 & 35,8 & 28,6 & 27,44 & Rather hot \\
\hline & & 12 Maret 2020 & 26,5 & 34,8 & 26,8 & 27,26 & Rather hot \\
\hline \multirow{3}{*}{5} & \multirow{3}{*}{$\begin{array}{l}\text { Jl. MT. } \\
\text { Haryono } \\
\text { (Alun- alun } \\
\text { Mejayan) }\end{array}$} & 15 Des 2019 & 26,8 & 32,3 & 28,0 & 26,82 & Cool \\
\hline & & 7 Jan 2020 & 25,8 & 33,6 & 24,8 & 26,88 & Cool \\
\hline & & 12 Maret 2020 & 24,4 & 33,8 & 24,8 & 26,64 & Cool \\
\hline \multirow{3}{*}{6} & \multirow{3}{*}{$\begin{array}{l}\text { Jl. Imam } \\
\text { Bonjol } \\
\text { (Sempedan } \\
\text { Sungai Kali } \\
\text { Kembang) }\end{array}$} & 15 Des 2019 & 24,8 & 31,8 & 28,6 & 26,32 & Cool \\
\hline & & 7 Jan 2020 & 23,8 & 30,4 & 24,8 & 25,84 & Cool \\
\hline & & 12 Maret 2020 & 23,0 & 26,6 & 25,8 & 24,92 & $\begin{array}{c}\text { Rather } \\
\text { cold }\end{array}$ \\
\hline \multirow{3}{*}{7} & \multirow{3}{*}{$\begin{array}{c}\text { J1. Sumatera } \\
\text { (Lapangan } \\
\text { Krajan) }\end{array}$} & 15 Des 2019 & 24,6 & 31,0 & 25,2 & 26,12 & cool \\
\hline & & 7 Jan 2020 & 24,4 & 29,8 & 27,2 & 25,84 & cool \\
\hline & & 12 Maret 2020 & 24,2 & 30,6 & 25,0 & 25,96 & cool \\
\hline
\end{tabular}

Based on the results of research on air temperature measurements starting from 6:00 to $18: 00$, it is known that the maximum air temperature occurs at 14:00 and the minimum at 06.00. The average temperature during the day is $31.7^{\circ} \mathrm{C}$. While at 06.00 , the average temperature is $24.8^{\circ} \mathrm{C}$. The maximum temperature is at 14.00 , and the minimum temperature occurs at 06.00 according to the opinion of (Samsudi, 2010) which states that the maximum temperature of the air occurs at 13.0014.00 (local hours) and reaches its maximum point at 05.00-06.00 (local hours).

The condition of the temperature rise which starts at 12.00-14.00 and then 
decreases until 18.00 is related to solar radiation Emitted to the surface of the earth. At 12.00-14.00, the radiation emitted by the sun approaches a line perpendicular to the surface of the earth. According to (Tjasyono, 2004), the phenomenon of extremely high temperatures when midday is holistic on the entire surface of the earth, which is mainly around the equator. In urban areas tend to be higher than sub-urban. This is due to the stretching of city activities and some heat sources that can trigger an increase city air temperatures such as vehicle mobility, industrial activities, households and various activities that involve burning fossil materials.

In the measurements made at 7 sample observation points in Mejayan Urban, it can be seen that the lowest temperature is in Sempedan Kali Kembang, which is $26.6^{\circ} \mathrm{C}$. Sempedan Kali Kembang has a total of 14 trees with five shrubs with an observation area of $100 \mathrm{~m}^{2}$. At Sempedan Kali Kembang, the surface cover covered by grass under the tree canopy is $70 \%$ so that with a higher number of trees and shrubs and the covered surface cover of grass under the tree canopy covering $70 \%$ of $100 \mathrm{~m}^{2}$, besides that around the Imam Bonjol road, whose suburbs are located in Kali Kembang, three schools have implemented Green School and the prohibition of public transportation, heavy and cars from entering the Imam Bonjol Street area causes the temperature in Sempedan Kali Kembang to be the lowest. Here are the results of temperature measurements at seven places above.

The types of plants which are located in Sempedan Kali Kembang are included in the level of plants that are good in $\mathrm{CO}_{2}$ absorption. The types of plants in Sempedan Kali Kembang include banyan (Ficus Benjamina), mango (Mangifera indica), Angsana (Pterocarpus indicus). Besides being able to absorb good $\mathrm{CO}_{2}$, the plant can produce $\mathrm{O}_{2}$ and $\mathrm{H}_{2} \mathrm{O}$ in large amounts (Peraturan Menteri Pekerjaan Umum Nomor: 05/PRT/M/2008, 2008).The existence of Green Open Space is also closely related to the number of shady trees. The more number of shady trees in an area, the quality of green space will be good (Prasetyo, 2012). With a good condition of Green Open Space, the air temperature in that place will be colder. This is because plants can absorb sunlight energy and can absorb $\mathrm{CO}_{2}$. Therefore, with a large number of plants and shade able to absorb sunlight energy and absorb $\mathrm{CO} 2$, the air temperature in the Sempedan Kali Kembang is low. The highest average temperature on 
measurements made for three days is in the big T-junction on Ahmad Yani Street. This is due to the large T-junction on Ahmad Yani Street 100\% land cover in the form of Bougainville flower plants, there are Tanjung trees, but there are only three trees with a canopy diameter of fewer than $1 \mathrm{~m}$ so that no vegetation in the form of trees can absorb sunlight. The unfavourable condition of Green Open Space at this location causes an increase in temperature. During the day at this location, the air is very high, so the air is hot, and at night the temperature remains high. The reason is that in this area no vegetation can absorb heat so that the big T-junction of Ahmad Yani Street gets hot all day. From the results of temperature measurements starting at 6:00 to 18:00 showed an increase in temperature and a decrease in temperature. The increase in temperature is in the range of 6:00 to $14: 00$ while the temperature decrease is in the range of 14:00 to 18:00. The increase and decrease in temperature that occurs at this time because it is influencer by solar radiation emitted to the surface of the earth. Besides, a large T-junction on Ahmad Yani Road is the primary arterial road leading to the provincial capital of Surabaya and connecting Solo City. So that throughout the day the traffic is weighty on the road.

\section{Analysis of Estimated Green Needs based on Oxygen requirements}

As is known in table 1. The number of Mejayan urban population at the end of 2019 was 15,569 people, and the area of Mejayan Urban area was 526.23 ha. According to (Pancawati, 2010), humans oxidize 3000 calories per day from their food using 600 litres of oxygen and produce 450 carbon dioxide. Usually, humans need 600 litres of oxygen, equivalent to 864 grams of oxygen every day so that it is converted to 0.864 $\mathrm{kg} /$ day. From these data, it can be sought human oxygen demand in urban Caruban.

Table 5. Oxygen requirements for humans in urban Caruban

\begin{tabular}{cccc}
\hline Total Population (people) & $\begin{array}{l}\text { Oxygen } \\
\text { /person/kg/day }\end{array}$ & Demand & Oxygen Consumption kg/ day \\
\hline 15.569 & 0,864 & 13451,616 \\
\hline
\end{tabular}


Motor vehicles are also consumers who consume large amounts of oxygen, so it is essential to be taken into account. Based on the classification of motor vehicles according to their use, (Purwatik et al., 2014) stated the amount of fuel used for gasoline motorized vehicles was $0.200-0.220 \mathrm{~kg} / \mathrm{PS}$ (horsepower). Hour (an average of 0.210 $\mathrm{kg} / \mathrm{PS}$. hour), with a fuel oxygen requirement of $2.77 \mathrm{~kg} \mathrm{O}_{2}$ to be able to produce energy. While the amount of fuel used for diesel motor vehicles is $0.140-0.180 \mathrm{~kg} / \mathrm{PS}$.hours (an average of $0.160 \mathrm{~kg} / \mathrm{PS}$.hours), with the need for every $1 \mathrm{~kg}$ of fuel is $2.86 \mathrm{~kg}$ oxygen. Operations of the vehicle for 5 hours/day. Based on data from field research, the types of motorized vehicles in the Caruban City area consist of 4 categories, as shown in Table 6, with the number of vehicles at the end of 2019 .

Table 6. Total oxygen demand for motorized vehicles

\begin{tabular}{lcccccc}
\hline \multicolumn{1}{c}{$\begin{array}{c}\text { Type of } \\
\text { Vehicle }\end{array}$} & Total & $\begin{array}{c}\text { Fuel } \\
\text { Requirements } \\
\text { (Kg/PS/Hour) }\end{array}$ & $\begin{array}{c}\text { Minimal } \\
\text { Power }\end{array}$ & $\begin{array}{c}\mathbf{O}_{\mathbf{2}} \text { Needs Every } \\
\mathbf{1} \text { liter of Fuel } \\
(\mathbf{K g})\end{array}$ & $\begin{array}{c}\mathbf{O}_{\mathbf{2}} \text { Needs } \\
\text { (Kg/Jam) }\end{array}$ & $\begin{array}{c}\mathbf{O}_{\mathbf{2}} \text { Needs } \\
\text { (Kg/day) }\end{array}$ \\
\hline Motor cycle & 17747 & 0,21 & 1 & 2,77 & 0,5817 & $49.159,19$ \\
\hline $\begin{array}{l}\text { Passenger } \\
\text { Vehicles } \\
(\text { Car) }\end{array}$ & 1668 & 0,21 & 20 & 2,77 & 11,634 & $4.620,36$ \\
\hline Truck & 171 & 0,16 & 50 & 2,86 & 22,88 & 489,06 \\
\hline Bus & 27 & 0,16 & 100 & 2,77 & 44,32 & 74,79 \\
\hline & & & & & & $54.343,4$ \\
\hline
\end{tabular}

Based on secondary data obtained with extensive satellite imagery, the green open space of Caruban City currently is 87.20 hectares.

The calculation of oxygen consumption for livestock is ignored as determined above because the urban area is tiny in the number of livestock according to geravkis calculations. The following is the estimated area of green space based on Oxygen consumption in Caruban city.

$$
\begin{aligned}
L t & =\frac{13451,616+54.343,400}{(54)(0,9375)(2)} m^{2} \\
& =133,92 \mathrm{Ha}
\end{aligned}
$$

Based on the two groups of consumers discussed above, it appears that motor vehicles are the most dominant oxygen consumers. While oxygen demand for humans tends to be less, see the results of the calculation of the need for Green Open Space based on oxygen requirements. Urban Mejayan needs 133.92 Ha of Green Open Space. 


\section{CONCLUSIONS}

Caruban City ideal temperature between $24.9{ }^{\circ} \mathrm{C}-27.5{ }^{\circ} \mathrm{C}$. The average temperature in the morning is $24.8^{\circ} \mathrm{C}$; the average temperature in the afternoon is $31.7^{\circ} \mathrm{C}$ and the average temperature in the afternoon is $26.3{ }^{\circ} \mathrm{C}$. Temperature conditions are quite cold for the six locations, with ideal temperatures for the current category between $25.8^{\circ} \mathrm{C}-26.9$ ${ }^{\circ} \mathrm{C}$, while for the rather cold categories at 24, $9{ }^{\circ} \mathrm{C}$, and one rather hot location located on Jalan Ahmad Yani, SoloSurabaya primary arterial road at an ideal temperature between $27.3^{\circ} \mathrm{C}-27.5{ }^{\circ} \mathrm{C}$. Caruban City green open space area

\section{E. REFERENCES}

BPS. (2019a). Kabupaten Madiun Dalam Angka. BPS Kabupaten Madiun.

BPS. (2019b). Kecamatan Mejayan Dalam Angka. BPS Kabupaten Madiun.

Dasuka, Y. P., Sasmito, B., \& Hani'ah. (2016). Analisis sebaran jenis vegetasi hutan alami menggunakan sistem penginderaan jauh. Jurnal Geodesi Undip, 5(2), 1-8.

Peraturan Menteri Pekerjaan Umum Nomor: $\quad$ 05/PRT/M/2008, 57 (2008).

Humaida, N., Prasetyo, L. B., \& Rushayati, S. B. (2016). Priority Assessment Method of Green Open Space (Case Study: Banjarbaru City). Procedia Environmental Sciences, 33(December), 354-364. https://doi.org/10.1016/j.proenv.20 16.03.086
87.20 hectares, still does not meet the needs of the ideal green space area of 132.86 hectares. Therefore, the shortage of green space is based on the oxygen demand of 45.66 hectares.

The results of this study are expected to provide recommendations in the application of Undang-Undang Tata Ruang Nomor 26 Tahun 2007 tentang penataan ruang mentioning urban spatial planning and drafted a Regional Regulation on Provision of Green Open Space and increasing the comfort of Caruban city dwelling in terms of the air environment.

Peraturan Pemerintah Republik Indonesia Nomor 3 Tahun 2019 Tentang Perubahan Atas Peraturan Pemerintah Nomor 52 Tahun 2010 Tentang Pemindahan Ibu Kota Kabupaten Madiun Dari Wilayah Kota Madiun ke Wilayah Kecamatan Mejayan Kabupaten Madiun Provinsi Jawa Ti, Pub. L. No. Peraturan Pemerintah Republik Indonesia No. 3 Tahun 2019, 7 (2019).

Pancawati, J. (2010). Analisis Kebutuhan Ruang Terbuka Hijau Di Kota Tangerang. In Bogor Agricultural University. IPB (Bogor Agricultural University).

Prasetyo, A. T. (2012). Pengaruh Ruang Terbuka HIjau (RTH) Terhadap Iklim Mikro di Kota Pasuruan. UM.

Purwatik, S., Sasmito, B., \& Hani'ah. (2014). Analisis Ketersediaan 
Ruang Terbuka Hijau (RTH) Berdasarkan Kebutuhan Oksigen. Jurnal Geodesi Undip, 3(3), 124135.

Samsudi. (2010). Ruang Terbuka Hijau Kebutuhan Tata Ruang Perkotaan Kota Surakarta. Journal of Rural and Development, Vol. 1(No. 1), Hal. 11-19.

Santi, Belinda, S., Rianty, H., \& Aspin. (2019). Identifikasi Iklim Mikro Dan Kenyaman Termal Ruang Terbuka Hijau Di Kendari. NALARs, 18(1), 23-33. https://doi.org/10.24853/nalars.18.1 .23-34

Setyani, W., Sitorus, S. R. P., \& Panuju, D. R. (2017). Analisis Ruang Terbuka Hijau Dan Kecukupannya Di Kota Depok. Buletin Tanah Dan Lahan, 1(1), 121-127.
Tjasyono, B. (2004). Klimatologi. ITB Press.

Wati, T., \& Fatkhuroyan, F. (2017). Analisis Tingkat Kenyamanan Di DKI Jakarta Berdasarkan Indeks THI (Temperature Humidity Index). Jurnal Ilmu Lingkungan, 15(1), 57. https://doi.org/10.14710/jil.15.1.57 $-63$

Xiao, X. D., Dong, L., Yan, H., Yang, N., \& Xiong, Y. (2018). The Influence of The Spatial Characteristics of Urban Green Space on The Urban Heat Island Effect in Suzhou Industrial Park. Sustainable Cities and Society, 40, 428-439. 